\title{
Pulsed electric field technology - Shelf life extension of milk
}

\author{
GSujatha, T Sivakumar, A Serma Saravana Pandian and K Chitrambigai
}

Received: 28 January 2021 / Accepted: 22 February 2021/ Published online: 07 June 2021

(C) Indian Dairy Association (India) 2021

\begin{abstract}
Application of Pulsed Electric field (PEF) in food processing is one of the innovative non thermal technologies which can be used as an alternative to traditional thermal processing. The nutritional and sensory qualities of the food are altered in thermal processing. As pulsed electric field inactivates microorganisms at ambient temperatures, organoleptic and nutritional properties of the food are retained in liquid foods such as milk, fruit juices. When compared to thermal processing, PEF processing is more energy efficient, as the processing time is only for few seconds. This study investigates the shelf life studies of raw milk processed using PEF technology. The quality control tests were done and physico chemical parameters were analysed after PEF processing. A mean value of $26.17 \pm 1.3$ was obtained for shelf life (in days) after PEF processing. The mean values of $6.58 \pm 0.02$ to $6.25 \pm 0.02$ and 0.14 \pm 0.00 to $0.18 \pm 0.01$ were obtained for $\mathrm{pH}$ and acidity respectively during the $1^{\text {st }}$ week to $4^{\text {th }}$ week of storage. Pulsed electric field technology has shown positive effects on inactivating pathogenic bacteria and reducing the number of spoilage microorganisms in milk.
\end{abstract}

Keywords: Physico chemical analysis, PEF, Quality Control, Shelf Life,

Consumers are increasingly getting aware of the taste, colour, flavour and nutritional value of the foods they eat. Fresh food contains all the nutrients needed for good health, but because it may not always be possible to obtain fresh food, preservation

Tamilnadu Veterinary and Animal Sciences University, Chennai 600 051, India

G Sujatha $(\bowtie)$

Tamilnadu Veterinary and Animal Sciences University, Chennai 600 051, India

Email:sujatha.g@tanuvas.ac.in becomes necessary (Canovas et al. 1999). Thermal processing has been most commonly used in the food industry to increase shelf life and maintain food safety by inactivating spoilage and pathogenic microorganisms. However, studies have shown that colour, flavour, and nutrients are degraded by heat. Now there is a demand for alternative methods of food preservation. Non thermal methods provide an option because they offer fresh, minimally processed foods with little loss of colour, flavour and nutrients (Asaad and Hilphy, 2012). The use of high intensity pulsed electric fields (PEF) is one of the emerging non thermal processes which accomplishes food preservation with short treatment times (Mercado et al. 1995). PEF technology is not intended to heat food. Rather, it involves the application of a short burst of high voltage to a food placed between two electrodes for only microseconds (Jeyamkondan et al. 1999).

A lab model PEF equipment for liquid food preservation was used to process the milk at room temperature. The independent variables were voltage, distance between electrodes, pulse width and number of pulses. Dependent variables were $\mathrm{pH}$, acidity, and shelf life. The electrodes used were parallel plate circular electrodes made of food grade stainless steel SS304. Raw milk samples were collected aseptically and transported to the lab under refrigerated condition from six different places of Alamathy village. Temperature of all the samples was adjusted to $30^{\circ} \mathrm{C}$ before PEF treatment. After processing, the samples were stored in glass bottles of $200 \mathrm{~mL}$ capacity and kept at $5^{\circ} \mathrm{C}$.

Quality control tests were conducted after PEF processing. As a platform test, temperature, organoleptic tests were carried out. Temperature was recorded after each trial using highly sensitive thermocouple to check the rise in temperature after processing. Colour and odour were determined using 9 points Hedonic scale rating by 10 selected untrained panellists. A sample volume of $100 \mathrm{~mL}$ of processed milk sample was given to the panellists to give their ratings in comparison with control.

Chemical tests such as clot on boiling test, $\mathrm{pH}$ and total titratable acidity were conducted daily. Five millilitres of sample was taken in a test tube and placed in boiling water bath for five minutes. Appearance of flakes/clots on the walls of the test tube indicated positive for the clot on boiling test. $\mathrm{pH}$ was determined with a 
Table 1 Quality control tests between control and PEF processed samples stored at $5^{\circ} \mathrm{C}(\mathrm{Mean} \pm \mathrm{SE})^{\circledR}(\mathrm{N}=6)$

\begin{tabular}{lllllc}
\hline Weeks & Sample(milk) & Colour & Odour & $\mathrm{pH}$ & Titratable acidity \\
\hline 1 Week & Control & $7.67 \pm 0.11$ & $7.33 \pm 0.16$ & $6.41 \pm 0.03$ & $0.16 \pm 0.00$ \\
& Processed & $7.67 \pm 0.11$ & $7.33 \pm 0.16$ & $6.58 \pm 0.02$ & $0.14 \pm 0.00$ \\
& $\mathrm{t}$ - value & $0.00^{\mathrm{NS}}$ & $0.00^{\mathrm{NS}}$ & $4.87^{* *}$ & $0.02^{* *}$ \\
\hline
\end{tabular}

Table 2 Quality control tests between PEF processed samples during the storage period (Mean $\pm \mathrm{SE})^{@}(\mathrm{~N}=6)$

\begin{tabular}{|c|c|c|c|c|c|}
\hline $\begin{array}{l}\text { Weeks } \\
1^{\text {st }} \text { Week } \\
2^{\text {nd }} \text { Week } \\
3{ }^{\text {rd }} \text { Week } \\
4{ }^{\text {th }} \text { Week } \\
\text { F - value }\end{array}$ & $\begin{array}{l}\text { Sample(Milk) } \\
\text { Processed } \\
\text { Processed } \\
\text { Processed } \\
\text { Processed }\end{array}$ & $\begin{array}{l}\text { Colour } \\
7.67 \pm 0.11^{\text {aA }} \\
7.65 \pm 0.11^{\text {aA }} \\
7.50 \pm 0.11^{\text {aA }} \\
7.58 \pm 0.14^{\text {aA }} \\
0.61\end{array}$ & $\begin{array}{l}\text { Odour } \\
7.33 \pm 0.16^{\mathrm{aA}} \\
7.58 \pm 0.14{ }_{\mathrm{aA}} \\
7.65 \pm 0.11^{\mathrm{aA}} \\
7.58 \pm 0.14{ }_{\mathrm{aA}} \\
0.20\end{array}$ & $\begin{array}{l}\mathrm{pH} \\
6.58 \pm 0.02^{\mathrm{aB}} \\
6.52 \pm 0.03^{\mathrm{aB}} \\
6.39 \pm 0.05^{\mathrm{aA}} \\
6.25 \pm 0.02^{\mathrm{bA}} \\
6.02^{* *}\end{array}$ & $\begin{array}{c}\text { Titratable acidity } \\
0.14 \pm 0.00^{\mathrm{aA}} \\
0.14 \pm 0.00^{\mathrm{aA}} \\
0.16 \pm 0.00^{\mathrm{aB}} \\
0.18 \pm 0.01 \\
19.07^{* *}\end{array}$ \\
\hline
\end{tabular}

digital $\mathrm{pH}$ meter at room temperature. The $\mathrm{pH}$ meter was calibrated using $\mathrm{pH}$ buffer of 4.0, 7.0 and 9.2. The acidity of milk was estimated by titration method using $0.1 \mathrm{~N} \mathrm{NaOH}$ solution. The titratable acidity was expressed as per cent lactic acid and was determined by titration of a known amount of milk with $0.1 \mathrm{~N}$ $\mathrm{NaOH}$ using phenolphthalein as indicator.

The data obtained were statistically analysed by one way analysis of variance (ANOVA). The temperature of the milk samples subjected to PEF processing was found to be unchanged. There was no increase in temperature after PEF processing. The colour and odour were determined using 9 points hedonic scale. Table 1 shows the colour and odour values rated in 9 points hedonic scale for control and PEF treated milk samples stored at $5^{\circ} \mathrm{C}$. Mean values of $7.67 \pm 0.11$ and $7.33 \pm 0.16$ were obtained for colour and odour for control and PEF processed samples during the $1^{\text {st }}$ week of storage. It was observed that there was no significant difference $(p>0.05)$ in colour and odour. It was also observed from table 2 that there was no significant difference $(\mathrm{p}>0.05)$ in colour and odour during the storage period of four weeks. Table 1 also shows the $\mathrm{pH}$ and titratable acidity of control and PEF processed samples during the $1^{\text {st }}$ week of storage. It was observed that the processed samples were highly significant $(p<0.01)$ when compared to the control samples after one week. Table 2 shows the $\mathrm{pH}$ and titratable acidity of PEF processed samples for 4 weeks stored at $5^{\circ} \mathrm{C}$. It was found that there was significant difference $(\mathrm{p}<0.01)$ in the $\mathrm{pH}$ and titratable acidity values between the weeks and decreasing trend in mean values of $\mathrm{pH}$ and increasing trend in mean values of titratable acidity were observed during the storage period.

\section{Conclusion}

It was observed that there was no significant difference in colour and odour between the control and PEF processed samples till the first week of storage period. It was also found that there was no significant difference in sensory attributes till $4^{\text {th }}$ week during the storage period at $5^{\circ} \mathrm{C}$. However, there was significant difference in $\mathrm{pH}$ and titratable acidity. The values of $\mathrm{pH}$ and acidity revealed that the shelf life of the PEF processed milk extended to $3-4$ weeks.

\section{References}

Asaad RS, Hilphy Al (2012) Electrical field (AC) for Non thermal milk pasteurisation. Nutr Food Sci 2:177

Canovas GVB, Gongora N, Pothakamury UR, Swanson BG (1999) Preservation of foods with pulsed electric fields. Academic Press, San Diego, CA. 13-15

Jeyamkondan S, Jayas DS, Holley RA (1999) Pulsed electric field processing of foods: A review. J Food Prot 62: 1088-1096

Mercado HV, Powers JR, Canovas GVB, Swanson BG (1995) Plasmin inactivation with pulsed electric fields. J Food Sci 60:1143-1146 